\title{
Educational Software in English to the awareness in a Preschool Education Supervised context
}

\author{
Patrícia Reis \\ ESE - Instituto Politécnico de \\ Castelo Branco \\ Castelo Branco, Portugal \\ patriciareis009@gmail.com
}

\author{
Henrique Gil \\ ESE - Instituto Politécnico de \\ Castelo Branco \\ CAPP - Universidade de Lisboa \\ Castelo Branco, Portugal \\ hteixeiragil@ipcb.pt
}

\author{
Margarida Morgado \\ ESE - Instituto Politécnico de \\ Castelo Branco \\ Castelo Branco, Portugal \\ marg.morgado@ipcb.pt
}

\begin{abstract}
Information and communication technologies play an increasingly important role in society, in the sense that all areas and professions make use of digital resources. The school can not be brushed off this reality, aim to create full subjects and integrated in society today. Educational software can be used very early in the education of children, but they must be carefully and monitoring. This article aims to present the results of the use of educational software in English to the awareness of context with children of pre-school education in kindergarten, nursery center Redemptorist Fathers - The smallest fox in White Castle, a 21 group children under 5 years. Early awareness of foreign language such as English can be started with digital multimedia capabilities and various software available on the market. However, the small study described the case reveals some resistance from parents and educators, in the preparation of these to choose and monitor the use of ICT by children, in addition to also highlight the self-interest of the children involved and their learning a few words in English language in different contexts of daily worked. The study opens perspectives on close monitoring needs of such uses and training of educators in the field of use of resources multilingual awareness in pre-school education.
\end{abstract}

Keywords- Educational Software; Information and Communication Technologies; Preschool Education.

\section{INTRODUCTION}

Today, ICT is present in all sectors and the day-to-day is crucial that children know this code technology in order to provide training spaces for their future social inclusion. Sensitization for a foreign language in Preschool Education, is growing as it gradually feels the need to include exposure of children to different languages at ages earlier, since children can acclimatise easily to different sounds a foreign language, in addition to the mother tongue. The implementation of this study took place during the Supervised Teaching Practice (PES) in pre-school, with the official practice guidance document [1] relying on knowledge of various codes, languages and languages in which may include ICT and English.

\section{EDUCATIONAL SOFTWARE}

Currently, there is no single concept of educational software, there are several concepts and definitions that arise.
What gives, the English term 'software' an educational character is its application in the teaching-learning process [2]. In turn, [3] indicates that the concept of 'educational software' is " $(. .$.$) todos los programas de uso general en el mundo$ empresarial (...) como por ejemplo: procesadores de textos, hojas de cálculo (...) Estos programas, aunque puedan desarrollar una función didáctica, no han estado elaborados específicamente con esta finalidade".

Although you can find many definitions of what is an educational software, all of which are centered on a perspective which states that, in the opinion of [4], the educational are "(...) programas informáticos concebidos para a finalidade (específica) de serem utilizados como meio didático de forma a facilitarem o processo de ensino e de aprendizagem."

Still on the same subject, [5] is of the opinion that they should have four basic characteristics in order to be able to motivate children, namely: “(...) ser desafiante[s], estimular a curiosidade, apelar à fantasia e permitir um elevado nível de controlo por parte das crianças".

\section{A. Educational Software 'Sunshine'}

he "Sunshine" is an educational software in order to enhance learning at the level of English, since this is not the native language of its users. This software is available on CDROM and provides access to songs, stories and activities related to different themes (geometric shapes, animals and even a brief approach to the Solar System.

This software is adapted to the age of the children present in this study, allowing explore various contents present in the Curriculum Guidelines in Preschool Education. Being one of the present study aims, awareness of the use of a foreign language (English), this software establishes a direct relationship with them. By using this software, it was also possible to give children the acquisition of certain skills in ICT (manipulate the computer mouse; develop skills in moving the screen, navigation between different screens, selection of activities and tools).

Taking into account the software types defined by [4], the "Sunshine" is part of the category "training / practice," the acquisition of skills by performing tasks and overcoming 
difficulties respecting the learning pace of each child. Figure 1 shows the corresponding home to the software Main Menu 'Sunshine':

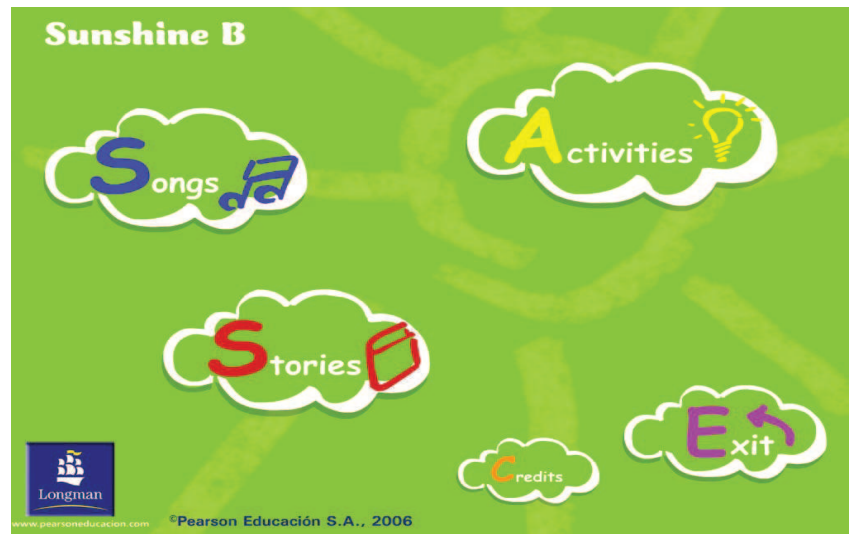

Fig. 1. Homepage of the 'Sunshine'.

For its part, Figure 2 shows the 'Activities' menu, where you can observe the proposed activities offered by the software 'Sunshine':

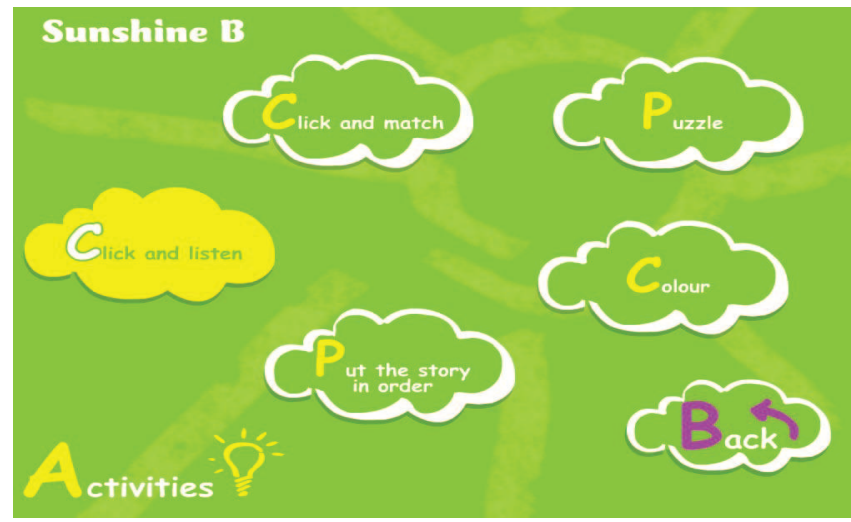

Fig. 2. Menu 'Activities' of 'Sunshine'.

\section{B. Educational Software 'AlphaEU'}

The Educational Software 'AlphaEU' belongs to a project with a joint initiative of some countries in Europe, in which Portugal is represented. This is an online software, the site "www.alphaeu.org". For this reason, this software is easy to access and access is free of charge for Educators, Teachers and Parents.

When accessing the site "www.alphaeu.org" is allowed access to a set of menus that lead to a set of tasks and useful information. The menus that may be of interest to children are the following: "alphabet books' and 'activities'. The remaining already be for use in adults, and some tips using these alphabets and useful design information.

With respect to software types presented in [4], this is also included in the category of "training / practice", since it allows performing jobs following the Paced each, and train skills and enhancing learning the level of different languages.

Figure 3 allows us to observe the contents concerning the software Main Menu 'AlphaEU':
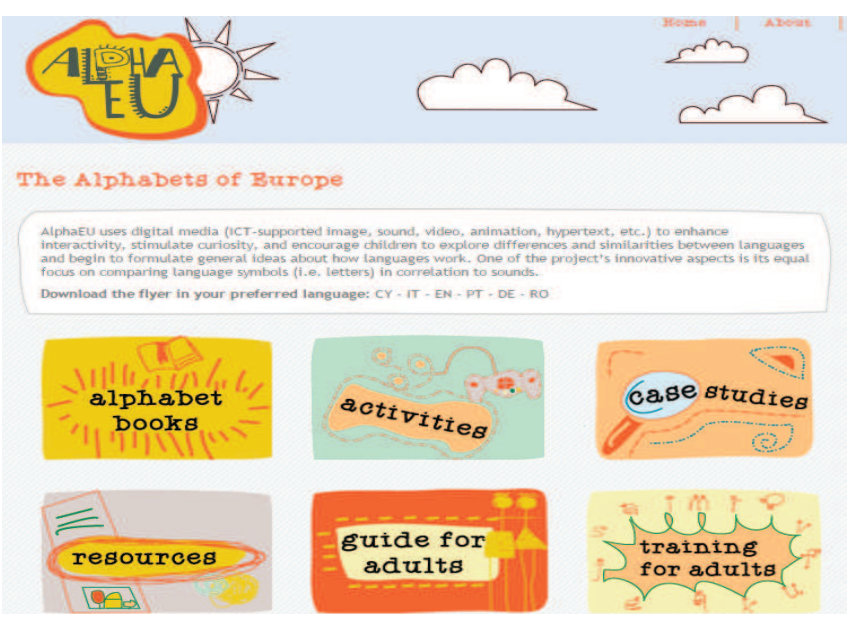

Fig. 3. Main menu of the software 'AlphaEU'.

Figure 4 shows the "Books Alphabet 'and their languages:

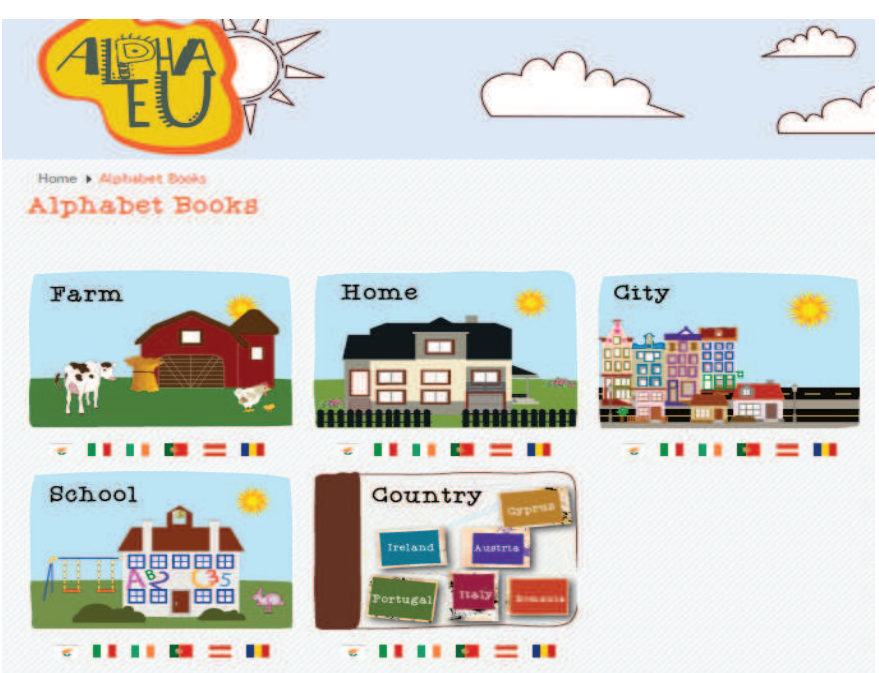

Fig. 4. 'Alpha Books' e differents languages.

\section{DESCRIPTION AND STUDY METHODOLOGY}

This study is based on qualitative research, which has resulted in a mixed approach, combining case study and action research. In this regard, [6] states the following: "As diferentes fases do processo de investigação qualitativa não se desencadeiam de forma linear mas interactivamente (...)". Once through action-research it was possible to interact with the study subjects, promoting a change in the behavior of the same, reflecting and improving every implementation meeting the needs that were feeling.

The instruments used in data collection were: semistructured interviews, questionnaire surveys, participant observation and field notes. All collected data were submitted to a data triangulation process, which included the opinions gathered from Childhood Educators of the institution, children and respective Guardians, allowing draw conclusions about the study. In this sense, [7] defines triangulation of data as 
"(...) the validity procedure where Researchers search for convergence Among multiple and different sources of information to form themes or categories in the study." Nevertheless, [9] is of the opinion that the triangulation of data "(...) strengthens the study by combining methods".

\section{A. Research question and objetives}

The research question that guided this study was: "Is the use of a digital multimedia resource can sensitize children, the level of pre-school education for the use of a foreign language?". The aim was to obtain data observed by using field notes what impact the use of a digital multimedia resource for awareness of a foreign language, in this case, English. To this end, it has set a research plan, which included methodologies and research tools appropriate for achieving the objectives necessary to implement this study, namely:

1) Promote the use of computer and multimedia digital resources in Preschool Education..

2) Propose and create conditions for a more systematic use of digital resources in Preschool Education for Educator and children.

3) Develop activities with the use of digital resources in English.

4) Establishing that the use of digital resources can sensitize children to a foreign language - English.

\section{B. Sessions of the implementation of the study}

The implementation of this study was done in seven sessions, each of which had its theme set. In these sessions we used the educational software "Sunshine" and "AlphaEU", always trying that there was a balance between both. The "Sunshine" was the first software to be used, having started with listening to a music related to the topic of the week 'Easter'. In this first session the children were shown surprises with the sounds heard in the music, but managed to understand the history conveyed in the music and a few words by repetition. Figure 5 illustrates one of the activities with the children:

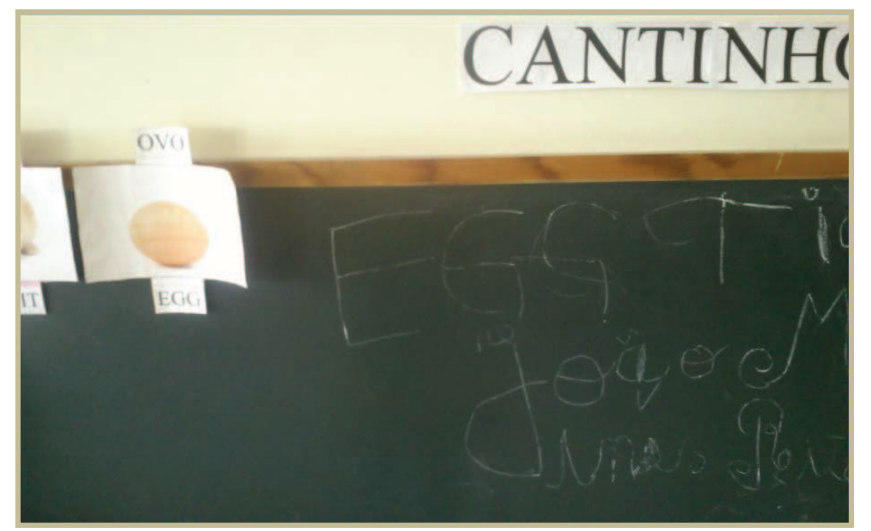

Fig. 5. Example of na activity with the educational software 'Sunshine'.

The following three sessions were dedicated to "AlphaEU." Through use of this feature is to validate the importance of diversity in the definition of objectives for the use of different resources. Children need to understand the reason for using that resource, to conduct that activity.
Allowed also understand the need to be a child playing on the computer, to be her own to discover and build knowledge. Initially, it was the educator that was pressing the local children showed, however, they began to lose interest. When were randomly chosen some children themselves to explore the software, they were motivated much more and showed more interest in the activity that was being performed. Figure 6 allows us to observe the operation of an activity related to the software 'AlphaEU':

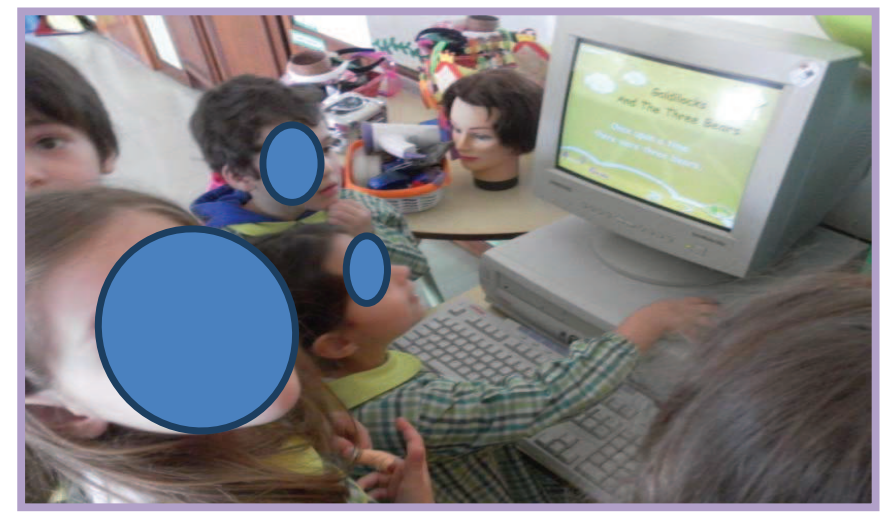

Fig. 6. An example of one activity through software 'AlphaEU'.

The remaining three sessions were devoted to the educational software "Sunshine." The first two were devoted to a free exploitation of children to use, so that they could know the best, since the unavailability of resources, not all children could have the same exploration opportunities resource. The last session was devoted to the story of a story in the English language and use of digital multimedia feature. In this last session, the children were very autonomous in decoding the message of the story heard, they have used some familiar words and have managed to find others who knew the discourse of history. Here are some examples collected from children: "Ah! Eu conheço aquela palavra! É bye bye, quer dizer adeus." (F); "Eu ouvi frog!” (S); "Estás a ver, o bird está ali em cima da árvore?” (N).

To this end, Figure 7 allows to observe an activity carried out within the framework (Figure 7):

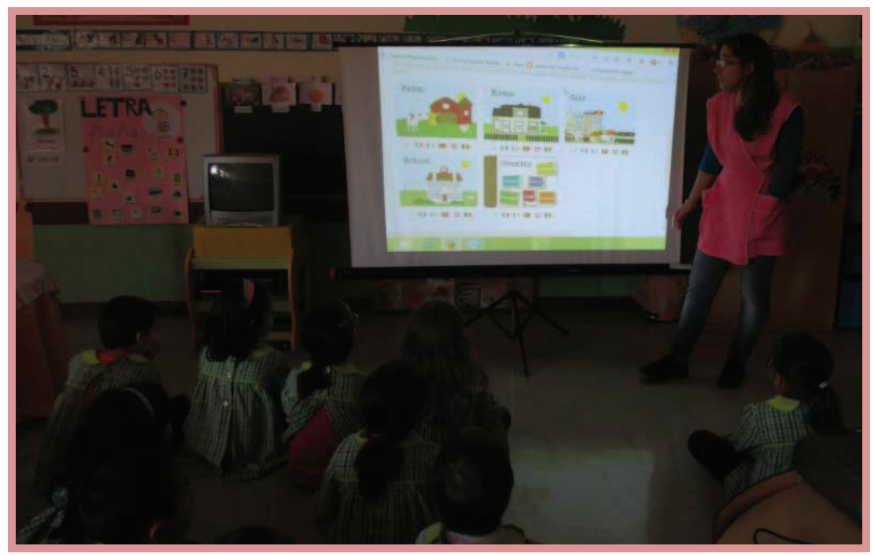

Fig. 7. Exploração de uma atividade através do software 'AlphaEU' com a exploração da palavra 'Egg'.. 
At the end of the implementation of the sessions was intended to achieve the proposed goals and already described, causing a change in the behavior of subjects, ie lead to ICT started to be most used in day-to-day as a learning resource. As stated by [8]: "É usando as tecnologias que o professor ensinará a trabalhar com elas. (...) As TIC são um instrumento ao serviço do professor, que assim poderá melhor explicar e problematizar a matéria que ensina".

Today, in our society, as stated [9] almost all tasks are dependent on ICT, can not be expected that children can grow up without knowing these resources. It is essential that the educator / teacher to adapt and support the children to join in society as full individuals, essential that they master new technologies.

\section{RESULTS AND MAIN CONCLUSIONS}

With the emergence and subsequent technological advance of the designated Information and Communication Technologies, today's society has undergone an obvious change in all areas, which led to a change in behaviors and routines of citizens, which extend naturally to educational environments, inside and outside the school.

The use of multimedia digital resources to educate children, the level of pre-school education for the use of a foreign language, while contextualize ICT as an interactive learning environment was achieved during the PES, not without many constraints as the lack of technological equipment or internet access, or the resistance of some parents who think to be an excessive use of technological resources. The study made it clear that the educational software used will meet the interests and needs of children of these ages.

It was not always easy to use the computer and digital resources in the room held the PES, although the two do not constitute uados software routines in the institution. The kindergarten teachers of the institution got to know the resource "AlphaEU" and proved willing to use such resources to their children, the positive results, not only in the context of sensitization to the English, but in other areas of Education Preschool. Both Childhood Educators of the institution as the Guardian, were open to the use of computer and multimedia digital resources in pre-school education, since safeguarded some risks, such as: a good integration of digital resources with other resources; moderate utilization is monitored thereof; knowledge of educational software quality and therefore careful choice of software to use.

The Childhood Educators of the institution during the interviews revealed to have some educational software on computers that use with children, although these are not always met adapted to the age group of children, leading to a lack of motivation and lack of interest. However, the "Sunshine" and the "AlphaEU" opened new 'ports' in this way, promoting their use and to a change of views in relation to other educational software.

If a few years ago the cost of acquiring educational software were significant, nowadays it is possible to find software quality and for free on the internet. Given this feature, this demand is already carried out either by
Educationalists of Childhood or the Guardian, which increasingly show available to adapt to this evolution of society by promoting the access of their children to ICT.

The necessary planning for the use of digital resources, the availability of computers in sufficient numbers with internet access proved to be a major concern for the respondents, since it is not possible to give the same opportunities to all children, with poor structuring physical conditions of the room.

By analyzing the collected data, it can be concluded that the use of digital resources can indeed teach children to a foreign language - English. The experiment conducted, although bounded in time and space, identifies the forms of relationship of children with words and concepts in a foreign language. The children used the words learned by rote and understood some of their meanings, which used well in other contexts.

The truth is that in multilingual environments that characterize contemporary societies, access to a global language of communication in the digital sphere, as is English, is a competence of Digital Natives, as the knowledge of technological code has proven so important as language learning.

Each well-used resource in education is a "treasure" that must be preserved. The use of ICT should be a measured and planned valence so that it can achieve positive results in this use. Do not hide the important role that Childhood Educator has in mediating technology to children. ICT will always be a valuable addition and a feature that can improve the quality of education of children. The Childhood Educator will have the responsibility of being the mediator between available resources and children, being important to remove the best possible experience of this interaction.

ICT should not only be used in school with the concept of 'education'; They can and should be used at home with the support of the Guardian, in order to enhance learning achieved in school and, perhaps, to realize new learning in a more innovative environment and in line with the profile of Digital Natives.

\section{References}

[1] L. Aires, Paradigma qualitativo e práticas de investigação educacional. Lisboa: Universidade Aberta, 2011.

[2] L. Amante, A Integração das Novas Tecnologias no Pré-Escolar: Um Estudo de caso. Tese de doutoramento em ciências da educação. Lisboa: Universidade Aberta, 2003.

[3] J. Cardoso, O Professor do Futuro. Lisboa: Editora Guerra \& Paz, 2013.

[4] H. Gil and M. Menezes, Software Educativo e a importância de uma «métrica».Disponível em: http://repositorio.ipcb.pt/bitstream/10400.11/922/1/Software\%20educati vo \%20e...pdf Acedido a: 10 de setembro de 2014.

[5] N. Golafshani, Understanding Reliability and Validity in Qualitative Research. The qualitative Report Vol. $8 n^{\circ}$ 4. Disponível em: http://www.nova.edu/ssss/QR/QR8-4/golafshani.pdf Acedido a: 1 de abril de 2015.

[6] S. Jucá, A relevância dos softwares educativos na educação profissional. Brasil: CEFET-CE, 2006. 
[7] P. Marquès, El Software Educativo. Disponível em: http://www.Imi.ub.es/te/any96/marques_software Acedido a: 8 de setembro de 2014

[8] M.E., (Orientações Curriculares para a Educação Pré-escolar. Lisboa: Ministério da Educação, 1997.
[9] R. Silva, Avaliação de Software Educacional: critérios para a definição da qualidade do produto.III Simpósio Nacional ABCiber. Brasil: ESPM/SP - Campus Francisco Gracioso, 2009. 